\title{
Assessment of Bread Wheat Genotypes Under Normal Irrigation and Water Stress
}

\author{
Henian, Manal M. ${ }^{1}$; B.R. Bakheit ${ }^{1}$; M.B.M. Ali ${ }^{1}$; M.A. El-Morshidy ${ }^{1}$ and \\ A.M. Amro' \\ ${ }^{1}$ Agronomy Dept., Fac. Agric., Assiut Univ., Egypt. \\ ${ }^{2}$ Botany and Microbiology Dept., Fac. Sci., Assiut Univ., Egypt. \\ Received on: $15 / 4 / 2020$ \\ Accepted for publication on: $23 / 4 / 2020$
}

\begin{abstract}
Thirty-two bread wheat genotypes included two local cultivars, ten Egyptian selected line, and twenty advanced inbred line from (CIMMYT) were grown in two experiments, i.e. normal irrigation under water stress during the 2016/2017 and 2017/2018 seasons in Agronomy Dept. Research Station, Faculty of Agriculture, Assiut University. Mean squares due to irrigations and genotypes were significant for all traits i.e. plant height, spike length, number of spikes/row, number of spikelets/spike, grain yield/row and 100 grain weight in each season and over the two seasons; suggesting that all traits were markedly affected by water stress and the presence of a wide range of differences among genotypes. The variance due to interaction between genotypes and irrigation (GxI) was significant for all studied traits. Mainly, the drought stress caused a relative loss in spike length, number of spikes/row, number of spikelets/spike, grain yield/row and 100 grain weight by $8.53,23.62,5.51,35.81$ and $10.83 \%$, respectively, as average of two years. The drought susceptibility index (DSI) was the powerful tool for discriminate the superior genotypes under water stress. Subsequently, the examined wheat genotypes were classified according to DSI into two groups: those were less than unity, there were tolerant to drought, while, those the DSI large than unity, there were susceptibility to drought. Some of these genotypes differed from season to season for (DSI). The superior genotypes using DSI were Giza 168 cultivar, C137 and MKI-19 and there were tolerant to drought stress. Finally the obtained results could propose the drought susceptible index as a good tool to select the most adapted genotypes under water stress condition.
\end{abstract}

Keywords: Bread wheat, Irrigation, water stress.

\section{Introduction}

Wheat is the most important cereal crop in the world in terms of production and area. It has been grown in a wide range of arid and semi-arid areas, where drought occurs frequently because of rainfall fluctuations in rain-fed regions and water scarity in irrigated regions (Sio-Se et al., 2006). Wheat occupies $17 \%$ of the world cultivated area and represents $35 \%$ of the staple food and $20 \%$ of diet calories (Braun et al., 2010).
In Egypt, wheat is the main winter cereal crop and widely distributed all over the country. The wheat cultivated area in Egypt is 3.26 million feddan with the actual production of 9.61 million tons (FAOSTAT, 2016). However, still there is a big gap between the consumption and local production (48\%). This gap could be narrowed by increasing local production of wheat via two ways. The first way by vertical expansion, i.e. increasing wheat production per unit area 
through the development of new cultivars of high yielding ability, early maturity, tolerance to biotic and abiotic stresses and the adoption of recommended cultural practices for growing these cultivars. The second way is horizontal expansion by extending wheat growing outside the Nile Valley in the desert land. But, the soil of these areas is sandy with low water holding capacity and thus exposes wheat plants to drought stress. Such drought stress causes great losses in wheat yield and its components (Clarke et al., 1992).

Drought stress tolerance is a complex trait that obstructed by low heritability and deficiency of successful selection approaches (Blum, 1988 and Kirigwi et al., 2004). Therefore, selection of new wheat genotypes should be adapted to drought stress. In addition, drought tolerance mechanism should be identified during the development of new cultivars in order to increase the productivity (Rajaram et al., 1996). High-yielding genotypes under optimum conditions may not be drought tolerant (Blum, 1988 and Sio-Se et al., 2006); therefore may studies preferred the selection under stress and adequate conditions (Clarke et al., 1992; Byrne et al., 1995 and Rajaram and Van Ginkle, 2001). Many researchers studied the effect of drought stress on yield and its components i.e. Abd Elghany (2019) concluded that drought stress at anthesis stage reduced number of spike/plant, number of grains/spike, 1000 kernel weight and grain yield/plant by $48.0,14.8,23.3$ and 79.0 , respectively.

The current study was aimed to (1) assessment of widely diverse thirty-two bread wheat genotypes under normal irrigation and water stress and (2) estimate drought susceptibility index for these genotypes under the studied conditions.

\section{Materials and Methods \\ A- Plant materials and growing conditions:}

A set of thirty two bread wheat genotypes were used in the current study. This set comprised of two Egyptian cultivars, 10 Egyptian lines provided by the late Prof. M. ElMorshidy, Agronomy Dept., Assiut, and 20 advanced inbred lines (AIL) obtained from CIMMYT (Table 1). These AIL lines were derived from different crosses and selected under different environments through shuttle breeding approach in CIMMYT. These thirty two genotypes were sown in a strip plot design with 3 replications. Each genotype was presented in a 2.5 meter long row with $30 \mathrm{~cm}$ inter-row spacing. 60 grains were sown for each row. The aforementioned genotypes were grown during two growing seasons (2016/2017 and 2017/2018) at Research Farm of Agronomy Dept., Faculty of Agriculture, Assiut University, Egypt (27.19 N, 31.16 E; clay Soil (Table 2). The optimal and water stress conditions were applied. In the optimal condition, genotypes were irrigated regularly; however, in the water stress condition, three irrigations were skipped, two during vegetative growth and one during flowering stage (Table 3 ).

B-The following characters were recorded:

1- Plant height (PH; cm): was measured as the distance from the ground surface to the base of the 
main culm spike using ten plants from each genotype. Subsequently, the average plant height of these ten plants was calculated for each replication.

2- Spikel length (SL; cm): was measured at harvesting as an average length of the main culm of ten spikes taken randomly from each genotype.
3- Number of Spikes/row (NS): determined by counting the number of fertile spikes/row.

4- Number of spikelets/spike (Nstes)

5- Grain yield/row (GY; g): was weighted as grain yield for each genotype.

6- 100-Grain Weight (GW; g): was recorded in grams $(\mathrm{g})$ by the mean weight of random 100-grain samples replication. 
Table 1. The name, pedigree and origin of studied genotypes.

\begin{tabular}{|c|c|c|c|c|}
\hline 竎总气。 & \begin{tabular}{|c|}
$\begin{array}{c}\text { Genotype } \\
\text { name }\end{array}$ \\
\end{tabular} & Cross Name & Selection History & Origin \\
\hline 1 & C102 & $\mathrm{PRL} / 2 * \mathrm{PASTOR}$ & \begin{tabular}{|c|} 
CGSS97Y00034M-099TOPB-027Y- \\
099M-099Y-099M-27Y-0B
\end{tabular} & $\begin{array}{c}\text { MXI13- } \\
\text { 14\MULTTESTIGOS } \ 3\end{array}$ \\
\hline 2 & C103 & KACHU \#1 & $\begin{array}{l}\text { CMSS97M03912T-040Y-020Y- } \\
\text { 030M-020Y-040M-4Y-2M-0Y }\end{array}$ & $\begin{array}{c}\text { MXI13- } \\
\text { 14\MULTTESTIGOS } \backslash 4\end{array}$ \\
\hline 3 & C108 & TAITA & $\begin{array}{l}\text { CMSS08Y00140S-099Y-099M- } \\
\text { 099NJ-099NJ-4WGY-0B }\end{array}$ & $\begin{array}{c}\text { MXI13- } \\
\text { 14\M35ES22SAWHT } 9\end{array}$ \\
\hline 4 & C109 & $\mathrm{KACHU//KIRITATI/2*TRCH}$ & $\begin{array}{c}\text { CMSS08Y00152S-099Y-099M- } \\
\text { 099Y-2M-0WGY } \\
\end{array}$ & $\begin{array}{c}\text { MXI13- } \\
\text { 14\M35ES22SAWHT \10 }\end{array}$ \\
\hline 5 & C112 & MUTUS//ND643/2*WBLL1 & $\begin{array}{l}\text { CMSS08Y00224S-099Y-099M- } \\
\text { 099NJ-099NJ-1 WGY-0B }\end{array}$ & $\begin{array}{c}\text { MXI13- } \\
\text { 14\M35ES22SAWHT \19 }\end{array}$ \\
\hline 6 & C113 & \begin{tabular}{|c|} 
ND643/2*WBLL1/4/WHEAR/KUKUN \\
A/3/C80.1/3*BATAVIA//2*WBLL1 \\
\end{tabular} & $\begin{array}{c}\text { CMSS08Y00234S-099Y-099M- } \\
\text { 099NJ-9WGY-0B } \\
\end{array}$ & $\begin{array}{c}\text { MXI13- } \\
\text { 14\M35ES22SAWHT\21 }\end{array}$ \\
\hline 7 & C114 & ND643/2*WBLL1//KACHU & $\begin{array}{c}\text { CMSS08Y00235S-099Y-099M- } \\
\text { 099NJ-4WGY-0B }\end{array}$ & $\begin{array}{c}\text { MXI13- } \\
\text { 14\M35ES22SAWHT } \backslash 22\end{array}$ \\
\hline 8 & C118 & $\begin{array}{c}\text { SERI.1B*2/3/KAUZ*2/BOW//KAUZ/5/ } \\
\text { CNO79//PF70354/MUS/3/PASTOR/4/B } \\
\text { AV92/6/ND643/2*WBLL1 } \\
\end{array}$ & $\begin{array}{c}\text { CMSS08Y00330S-099Y-099M- } \\
\text { 099Y-12M-0WGY }\end{array}$ & $\begin{array}{c}\text { MXI13- } \\
\text { 14\M35ES22SAWHT \33 }\end{array}$ \\
\hline 9 & C120 & CHEWINK \#1/MUTUS & $\begin{array}{c}\text { CMSS08Y00485S-099Y-099M- } \\
\text { 099Y-5M-0WGY }\end{array}$ & $\begin{array}{c}\text { MXI13- } \\
\text { 14\M35ES22SAWHT \43 }\end{array}$ \\
\hline 10 & C124 & MUNAL*2/WESTONIA & \begin{tabular}{|c|} 
CMSS08Y00833T-099TOPM-099Y- \\
099M-099NJ-099NJ-8WGY-0B
\end{tabular} & $\begin{array}{c}\text { MXI13- } \\
\text { 14\M35ES22SAWHT } \backslash 68\end{array}$ \\
\hline 11 & C128 & WBLL1 $* 2 /$ BRAMBLING*2//BAVIS & \begin{tabular}{|c|} 
CMSS08Y00915T-099TOPM-099Y- \\
099M-099NJ-12WGY-0B \\
\end{tabular} & $\begin{array}{c}\text { MXI13- } \\
\text { 14\M35ES22SAWHT } \backslash 91 \\
\end{array}$ \\
\hline 12 & C129 & $\begin{array}{c}\text { CHYAK1 } * 2 / 3 / \text { HUW234+LR34/PRINIA } \\
\text { //PFAU/WEAVER }\end{array}$ & \begin{tabular}{|c|} 
CMSS08Y00931T-099TOPM-099Y- \\
099M-099NJ-099NJ-1WGY-0B \\
\end{tabular} & $\begin{array}{c}\text { MXI13- } \\
\text { 14\M35ES22SAWHT } \ 92\end{array}$ \\
\hline 13 & C134 & $\begin{array}{c}\text { WHEAR } / / 2 * \text { PRL } / 2 * \text { PASTOR/3/QUAIU } \\
\# 1\end{array}$ & $\begin{array}{c}\text { CMSS08B00510S-099M-099NJ- } \\
\text { 099NJ-3WGY-0B }\end{array}$ & $\begin{array}{c}\text { MXI13- } \\
\text { 14\M35ES22SAWHT } \backslash 109\end{array}$ \\
\hline 14 & C137 & BLOUK \#1/DANPHE \#1//BECARD & \begin{tabular}{|c|} 
CMSS08B00631T-099TOPY-099M- \\
099NJ-099NJ-7WGY-0B
\end{tabular} & $\begin{array}{c}\text { MXI13- } \\
\text { 14\M35ES22SAWHT } \backslash 113\end{array}$ \\
\hline 15 & C138 & \begin{tabular}{|c|} 
BLOUK \\
\#1/4/WHEAR/KUKUNA/3/C80.1/3*BA \\
TAVIA//2*WBLL1/5/MUNAL \#1 \\
\end{tabular} & \begin{tabular}{|c|} 
CMSS08B00633T-099TOPY-099M- \\
099NJ-11WGY-0B
\end{tabular} & $\begin{array}{c}\text { MXI13- } \\
\text { 14\M35ES22SAWHT } \backslash 114\end{array}$ \\
\hline 16 & C142 & $\begin{array}{c}\text { CROSBILL } \\
\text { \#1/DANPHE/7/CNDO/R143//ENTE/ME } \\
\text { XI_2/3/AEGILOPS SQUARROSA } \\
\text { (TAUS)/4/WEAVER/5/2*KAUZ/6/PRL/ } \\
2 * \text { PASTOR }\end{array}$ & $\begin{array}{c}\text { CMSS08B00659T-099TOPY-099M- } \\
\text { 099NJ-099NJ-14WGY-0B }\end{array}$ & $\begin{array}{c}\text { MXI13- } \\
14 \backslash \mathrm{M} 35 \mathrm{ES} 22 \mathrm{SAWHT} \backslash 122\end{array}$ \\
\hline 17 & C144 & $\begin{array}{c}\text { MU- } \\
\text { TUS//KIRITATI/2*TRCH/3/WHEAR/K } \\
\text { RONSTAD F2004 } \\
\end{array}$ & $\begin{array}{c}\text { CMSS08B00764T-099TOPY-099M- } \\
\text { 099NJ-26WGY-0B }\end{array}$ & $\begin{array}{c}\text { MXI13- } \\
\text { 14\M35ES22SAWHT } \backslash 135\end{array}$ \\
\hline 18 & C146 & WAXWING*2/TUKURU//2*FRNCLN & \begin{tabular}{|c|} 
CMSS08B00860T-099TOPY-099M- \\
099NJ-099NJ-39WGY-0B
\end{tabular} & $\begin{array}{c}\text { MXI13- } \\
\text { 14\M35ES22SAWHT } \backslash 153\end{array}$ \\
\hline 19 & C147 & FRANCOLIN \# $1 * 2 / / \mathrm{ND} 643 / 2 *$ WBLL1 & $\begin{array}{c}\text { CMSS08B00866T-099TOPY-099M- } \\
\text { 099NJ-099NJ-32WGY-0B }\end{array}$ & $\begin{array}{c}\text { MXI13- } \\
\text { 14\M35ES22SAWHT } \backslash 160\end{array}$ \\
\hline 20 & C148 & BECARD//KIRITATI/2*TRCH/3/BECARD & \begin{tabular}{|c|} 
CMSS08B00888T-099TOPY-099M- \\
099NJ-35WGY-0B
\end{tabular} & $\begin{array}{c}\text { MXI13- } \\
\text { 14\M35ES22SAWHT } \backslash 166 \\
\end{array}$ \\
\hline 21 & $\begin{array}{l}\text { Assiut- } \\
217\end{array}$ & Assiut-217 & \multirow{10}{*}{ Developed by Dr. El-Morshidy } & \multirow{12}{*}{ Egypt } \\
\hline 22 & $\begin{array}{l}\text { Assiut- } \\
230\end{array}$ & Assiut-230 & & \\
\hline 23 & $\begin{array}{c}\text { Assiut- } \\
401\end{array}$ & Assiut-401 & & \\
\hline 24 & $\begin{array}{l}\text { Assiut- } \\
704\end{array}$ & Assiut-704 & & \\
\hline 25 & $\begin{array}{l}\text { Assiut- } \\
733\end{array}$ & Assiut-733 & & \\
\hline 26 & MK1-10 & MK1-10 & & \\
\hline 27 & MK1-20 & MK1-20 & & \\
\hline 28 & Mubarak & Mubarak & & \\
\hline 29 & sel-188 & sel-188 & & \\
\hline 30 & sel-542 & sel-542 & & \\
\hline 31 & Giza-168 & Giza-168 & \begin{tabular}{|c} 
MIL/Buc/SeriCM93046-8M-04-0M- \\
2Y-OB \\
\end{tabular} & \\
\hline 32 & Sids-12 & Sids-12 & \begin{tabular}{|c|} 
BUC//7C/ALD/5/MAYA74/ON//1160 \\
$.147 / 3 / \mathrm{BB} / \mathrm{GLL} / 4 / \mathrm{CHAT}$ S"/6/MAY \\
$\mathrm{A} / \mathrm{VUL} / / \mathrm{CMH} 74 \mathrm{~A} .63014 * \mathrm{SX}$ \\
\end{tabular} & \\
\hline
\end{tabular}


Website: www.aun.edu.eg/faculty_agriculture/journals_issues_form.php E-mail:ajas@aun.edu.eg

Table 2. Soil chemical and physical properties of the experimental.

\begin{tabular}{|l|c|c|c|}
\hline Soil properties & Assiut site & Soil properties & Assiut site \\
\hline 1- Physical properties & & 2- Chemical properties & \\
sand \% & 25.90 & PH(1:2.5) suspension & 7.80 \\
silt \% & 24.70 & Organic matter \% & 1.62 \\
clay \% & 49.40 & Total nitrogen \% & 0.09 \\
Text grade & clay & Total CaCo $\%$ & 1.20 \\
Water saturation & 71.2 & & \\
Field capacity & 44.2 & & \\
\hline
\end{tabular}

Table 3. Irrigation schedule for experiment.

\begin{tabular}{|c|c|c|c|c|c|}
\hline \multicolumn{3}{|c|}{ Assiut 2017 } & \multicolumn{3}{c|}{ Assiut 2018 } \\
\hline Date & Optimal & Drought & Date & Optimal & Drought \\
\hline $2 / 1 / 2017$ & + & + & $25 / 12 / 2017$ & + & + \\
\hline $20 / 1 / 2017$ & + & - & $12 / 1 / 2018$ & + & - \\
\hline $5 / 2 / 2017$ & + & - & $27 / 1 / 2018$ & + & - \\
\hline $8 / 2 / 2017$ & - & + & $12 / 2 / 2018$ & - & + \\
\hline $19 / 2 / 2017$ & + & - & $27 / 2 / 2018$ & + & - \\
\hline $6 / 3 / 2017$ & + & + & $14 / 3 / 2018$ & + & + \\
\hline $21 / 3 / 2017$ & + & - & $1 / 4 / 2018$ & + & - \\
\hline
\end{tabular}

+ indicates irrigation was given, - irrigation was skipped

\section{7- Drought susceptibility index} (DSI):

Drought susceptibility index was calculated according to the method of Fischer and Maurer (1978). Yield of individual genotype was determining under stress (Yd) and favorable well-water (Yw) conditions. Average yield of all genotype under drought $(\times d)$ and well-watered conditions $(\times \mathrm{w})$ were used to calculate drought intensity (D) as: $\mathrm{D}=(1-$ $\left.\times \mathrm{d} / \times_{\mathrm{w}}\right)$. The mean drought susceptibility index (DSI) of individual genotype was calculated as: $\mathrm{S}=(1-$ $\mathrm{Yd} / \mathrm{Yw}) / \mathrm{D}$.

\section{Statistical analysis}

\section{1- Separate and combined analyses:}

The separate analysis of variance of the genotypes evaluation was done on plot mean basis according to Gomez and Gomez (1984). RLSD were used to compare means according to ElRawi and Khalafala (1980).

Combined analysis of both normal irrigation and water stress was performed to test the homogeneity of variance according to Bartlett's test.

Analysis of variance for studied traits were analyzed using PROC GLM in SAS V.9.0 (The SAS Institute Inc., Cary, NC, USA).

Genotypes with average susceptibility or tolerance to drought have "S" value of 1.0 values, less than 1.0 indicate less susceptibility and great tolerance to drought. Meanwhile, a value of $\mathrm{S}=0.0$ indicates maximum possible drought resistance (no effect of drought on yield).

\section{Results and Discussion}

The results obtained from the current investigation could be presented as follows: 
A- Analysis of variance for agronomical traits of bread wheat genotypes:

The separate analysis revealed that the significant differences were obtained among of the genotypes and their interaction with irrigation treatments as well as between the two irrigation treatments, revealing the genetic differences of the genotypes and their different interaction with water stress (Table 4).

Moreover, combined analysis of variance for agronomical characteristics studied over the two seasons under normal and water stress irrigation are presented in Table 5. The differences between years (Y) were significant for all studied traits except for plant height $(\mathrm{PH})$ and spike length (SL). There were significant differences between irrigation treatment (normal and water stress) for all studied traits. The interaction between years (Y) and irrigation (I) showed significant differences for all traits except for number of spikelets (Nstes). There were significant differences among genotypes for all studied traits. The interaction between years $(\mathrm{Y})$ and genotypes $(\mathrm{G})$ showed significant differences for all traits. The interaction between genotypes (G) and irrigation (I) showed significant differences for all traits. Equally, the interaction between genotypes $(\mathrm{G})$, years (Y), irrigation (I) showed significant differences for all traits, except for number of spikelets (Nstes) and 100- grain weight (GW).

The obtained results proposed the different genetic make-up of those wheat genotypes under the study. These results are in line with those obtained by Kheiralla et al. (1997), Ahmed (2003), Abd El-Ghany et al. (2016) and Abo-Sapra (2019). 


\section{B- Mean of the genotypes under normal irrigation and water stress conditions: \\ 1-Plant height, cm:}

In 2016/2017 season, the average of plant height under normal irrigation conditions ranged from 86.67 for genotype $(\mathrm{C} 103)$ to $112.00 \mathrm{~cm}$ for genotype $(\mathrm{C} 120)$ with an average of $101.63 \mathrm{~cm}$. Also, it ranged from 83.33 for (Giza-168) to $103.33 \mathrm{~cm}$ for Assiut-217 with an average of 93.71 $\mathrm{cm}$ under water stress (Table 6).

In 2017/2018 season, plant height under normal irrigation conditions varied from 89.67 for genotype (C109) to $108.00 \mathrm{~cm}$ for (MK1-20) with an average of $100.92 \mathrm{~cm}$. Moreover, it ranged from 76.33 for the genotype (C103) to $97.67 \mathrm{~cm}$ for genotype (C144) with an average of $90.11 \mathrm{~cm}$. under water stress.

The combined average of plant height, under normal irrigation ranged from 90.33 for genotype (C109) to $108.00 \mathrm{~cm}$ for Assiut-217 and Assiut-401 with an average of $101.27 \mathrm{~cm}$. Also, under water stress it ranged from 81.50 for genotype (C103) to 96.83 for Sel-542 with an average of $91.91 \mathrm{~cm}$ (Table 6).

The results clear that the shortest genotype was genotype (C103) but the longest one was Assiut-217 in combined average as done also in the first year. Plant height of all genotypes was decreased by water stress.

Decreasing by water stress accounted for $7.79,10.70$ and $9.24 \%$ from normal irrigation in the first, second and combined over the two seasons means (Table 6). Such decrease ranged from 0.0 for genotype C103 to $18.15 \%$ for genotype C120 in 2016/2017 season. Also, decreasing in second season ranged from 1.38 for genotype C138 to $22.37 \%$ for genotype $\mathrm{C} 103$. As well as the combined over the two seasons the decrease ranged from 2.08 for genotype $\mathrm{C} 138$ to $16.77 \%$ for genotype Assiut-733.

Sixteen, sixteen and seventeen genotypes were less susceptible or tolerance to drought as measured by drought susceptibility index (DSI) in the first, second and over two seasons, respectively, because they have DSI less than unity.

These results are in line with these obtained by Mohamed and Tammam (1999), Kadam et al. (2017) and Abo-Sapra (2019). 
2- Spike length, cm:

In the first season, spike length under normal irrigation ranged from 11.00 for genotype (C138) to 14.33 $\mathrm{cm}$ for Assiut-230 and (MK1-20) with an average of $12.35 \mathrm{~cm}$. Under water stress, spike length varied from $9.33 \mathrm{~cm}$ for (Sel-188) to $13.33 \mathrm{~cm}$ for Assiut-230 with an average of 11.68 $\mathrm{cm}$ (Table 7).

In the second season, spike length under normal irrigation ranged from $10.67 \mathrm{~cm}$ for genotypes (C137), (C138) and (MK1-10) to 14.33 for Sel542 with an average of $11.96 \mathrm{~cm}$. Moreover, under water stress, spike length ranged from $9.00 \mathrm{~cm}$. for genotype (138) to 13.00 for Sel-542 with an average of $10.56 \mathrm{~cm}$ (Table 7).

The combined over two seasons the average of spike length under normal irrigation ranged from 10.83 $\mathrm{cm}$ for genotype (C138) to $13.83 \mathrm{~cm}$ for Sel-542 with an average of 12.16 $\mathrm{cm}$. Under water stress, spike length ranged from $9.83 \mathrm{~cm}$ for genotype (C138) to $12.67 \mathrm{~cm}$ for Sel-542 with an average of $11.12 \mathrm{~cm}$ (Table 7).

Generally, means of spike length for all genotypes were higher under normal irrigation than water stress in both and over the two seasons (Table 7).
The spike length was decreased by $5.48,11.67$ and $8.53 \%$ under water stress compared to normal conditions in first, second and over the two seasons, respectively (Table 7).

These results are in agreement with there obtained by Kheiralla et al. (2004) and Abo-Sapra (2019).

Drought susceptibility index (DSI) of spike length (Table 7) indicated that sixteen, seventeen and nineteen genotypes tend to be tolerant to drought in first, second over the two seasons, respectively, were less than unity. Such results could be expected because spike length is mainly genetic make-up, and water stress affected grain filling and or fertility of the portion of the spike than spike length itself. These results are in line with those reported by Kadam et al. (2017) and Abo-Sapra (2019).

\section{3-Number of spikes/ row:}

In 2016/2017 season, number of spikes/row under normal irrigation ranged from 134.67 for genotype (C128) to 415.33 spikes/ row for Assiut-230 with an average of 264.70 . Meanwhile, under water stress, it ranged from 108.00 for genotype (C128) to 286.33 for Assiut-230 with an average of 193.18 spikes/row (Table 8 ). 
In 2017/2018 season, number of spikes/row under normal irrigation ranged from 133.33 for Assiut-704 to 280.33 for Assiut-230 with an average of 189.93. Also, under water stress it ranged from 96.00 for Assiut704 to 201.00 for MK1-10 with an average of 154.05 spikes/ row (Table 8).

The combined average of number of spikes/row under normal irrigation ranged from 134.17 for genotype (C128) to 347.83 for genotype Assiut-230 with an average of 227.31. Meanwhile, under it ranged from 116.67 for genotype (C128) to 229.83 for genotype Mubarak with an average of 173.61 spikes/row under water stress.

Generally, water stress reduced number of spikes/row by 27.02, 18.89 and $23.62 \%$ compared to normal irrigation in the first, second, and over the two seasons over all genotypes, respectively (Table 8).

Number of spikes/row of the different genotypes differed in rank from normal irrigation to water stress, and from season to season. The combined means indicated that genotype Assiut-230 was the best under normal irrigation. Also, genotype C137 was the best one under water stress, revealing to possess the gene tolerance to stress.
The best genotype in number of spikes/row not always the best in grain yield indicating that other characters such as spike length, grain weight and number of grains /spike are also contributors to grain yield. These results are in agreement with those obtained by Schmidt (1983) who found that drought stress caused less of tillers; Kheiralla et al (2004) found that skipping irrigation at stage before milk stage reduced number of spikes $/ \mathrm{m}^{2}$. Moreover, Abo-Sapra (2019) reported that water stress reduced number of spikes $/ \mathrm{m}^{2}$ by 9.8 , 10.7 and $10.2 \%$ compared over all genotypes to normal irrigation in the first, second and over the two seasons, respectively.

Drought susceptibility index (DSI) of some genotypes varied from season to season. Sixteen, nineteen and eighteen genotypes were less than unity for drought susceptibility index in first, second and over the two seasons respectively and could be considered tolerant to drought respect to number of spikes/row (Table 8).

These results are in line with those obtained by Abo-Sapra (2019) who found that drought susceptibility index of some genotypes varied from year to year. 
4- Number of spikelets/spike:

In the first season, under normal irrigation, number of spikelets/spike ranged from 20.33 for genotypes (C103) and (C138) to 27.00 for Sel188 with an average of 22.67. Number of spikelets ranged from 19.00 for Giza-168 to 25.00 for Sel-188 with an average of 21.38 under water stress (Table 9).

In the second season, under normal irrigation, number of spikelets/ spike ranged from 19.0 for genotypes (C109, C142, Assiut-230 and Assiut-401) to 23.00 for Sel-542 with an average of 20.67. Moreover, under water stress, the number of spikelets ranged from 17.33 for genotype (C129) to 21.67 for Entries (C114 and C148) with an average of 19.57.

The combined average for number of spikelets under normal irrigation ranged from 20.0 for genotype (C138) to 23.67 for Sel-188 with an average of 21.67. Moreover, it varied from 18.67 for genotype (C142) to 22.67 for Sel-188 with an average of 20.47 under water stress (Table 9).

Some genotypes significantly surpassed average in number of spikelets/spike. The superior geno- types overall seasons and water stress could to improve number of spikelets/spike and consequently grain yield in wheat breeding programs.

The reduction in number of spikelets/spike due to water stress in the first, second and over the two seasons were $5.70,5.29$ and $5.51 \%$ respectively, compared to normal irrigation. Generally, water stress reduced number of spikelets/spike and consequently number of grains/spike compared to normal irrigation.

These results are in line with those reported by Aggarwal et al. (1986), Afiah et al. (2018) and AboSapra (2019).

Number of spikelets/spike of the different genotypes differed in rank from normal irrigation to water stress, and from season to season. The combined means indicate that some genotypes were the best under normal irrigation and some of them were also the best under water stress.

Drought susceptibility index (DSI) of some genotypes varied from season to season. Fifteen, twenty two and eighteen genotypes could be considered tolerant to drought stress (Table 9). 


\section{5- Grain yield/row, gm:}

In 2016/2017 season, grain yield/row under normal irrigation ranged from 322.27 for genotype (C128) to 709.51 for Assiut-401 with an average of $475.75 \mathrm{~g}$. Tweleve genotypes were significantly and surpassed the average grain yield/row. Under water stress, grain yield/row varied from 111.66 for genotype (C103) to 363.05 for Assiut-733 with an average of $282.21 \mathrm{~g}$. Nine genotypes were significantly and surpassed the average grain yield/row.

In 2017/2018 season, grain yield/row under normal irrigation ranged from 250.27 for MK1-20 to 564.29 for Assiut-401 with an average of $359.10 \mathrm{~g}$. Five genotypes were significantly surpassed the average grain yield/row. Moreover, it ranged from 156.28 for genotype (C142) to 341.81 for genotype (C144) with an average of $253.65 \mathrm{~g}$ under water stress. Seven genotypes were significantly surpassed the average grain yield/row.

The combined average of grain yield/row under normal irrigation ranged from 293.94 for genotype (C128) to 636.9 for Assiut-401 with an average of $417.43 \mathrm{~g}$. Eleven genotypes were significantly surpassed the average grain yield/row. Under water stress, grain yield/row ranged from 183.29 for genotype (C103) to 345.71 for (MK1-10) with an average of 267.93g. Nine genotypes were sig- nificantly surpassed the average grain yield/row.

The obtained results may be due to the normal irrigation produce more metabolites required for increasing all agronomical traits than the water stress. Also, the role of water encouraging metaebolite processes, consequently effective on the all agronomical traits.

Moreover, some genotypes gave highly significantly grain yield/row. Those genotypes could be used to improve grain yield/row. The reductions in grain yield/plot due to water stress in the first, second and over both season were $40.68,29.37$ and $35.81 \%$ compared to normal irrigation conditions, respectively (Table10). Pal et al. (1979) found that reduction in grain yield due to reached to water stress $60 \%$. Also, Sayed (1982) reported that reduction in grain yield was $80 \%$. Kobata et al. (1992) showed that the grain yield was reduced under water stress by $33 \%$. Salem (2005) reported that full irrigation treatment significantly maximized grain yield/ha and its components were significant differences. Denčić et al. (2000) found that decreasing soil moisture caused significant reduction in grain yield. Kheiralla and Ismail (1995) stated that low soil moisture reduced grain yield. Blum (1996) indicated that under severe moisture-stress conditions, Yp and yield are negatively associated. 
Abo-Sapra (2019) reported that the reductions in grain yield $/ \mathrm{m}^{2}$ due to water stress in the first, second and over two seasons were 22.0, 19.9 and $20.9 \%$ compared to normal irrigation conditions, respectively.

Drought susceptibility index indicated that the eighteen, twenty and eighteen genotypes were tolerant to water stress in first, second and over two seasons. Some of these genotypes were low yielding. The other genotypes could be considered susceptible to drought. Also, some of those genotypes differed from season to season for DSI.

\section{6- The 100-grain weight, gm:}

In the first season, under normal irrigation the 100-grain weight ranged from 3.72 for genotype (C103) and Giza-168 to 4.74 for genotype (C128) with an average of $4.22 \mathrm{~g}$. Under water stress it ranged from 3.36 for Sids-12 to 4.53 for genotype (C128) with an average of $3.82 \mathrm{~g}$.
In the second season, under normal irrigation, the 100- grain weight ranged from 4.31 for genotype (C112) to 5.21 for MK1-10 with an average of $4.71 \mathrm{~g}$. Moreover, under water stress, the 100-grain weight ranged from 3.81 for genotypes (C138) and (C146) to 4.54 for Assiut733 with an average of $4.15 \mathrm{~g}$.

The combined average for 100grain weight under normal irrigation ranged from 4.02 for genotype (C112) to 4.80 for genotype (C148) with an average of $4.47 \mathrm{~g}$. Five genotypes were significantly surpassed the average 100-grain weight. Moreover, under water stress, the 100-grain weight varied from 3.67 for genotype (C146) to 4.33 for genotype (C128) with an average of $3.98 \mathrm{~g}$ in (Table11). Two genotypes (C128 and 129) were significantly surpassed the average 100 -grain weight. 
The reductions in 100- grain weight due to water stress in the first, second and both seasons were 9.45 , 12.07 and $10.83 \%$ compared to normal irrigation, respectively. Sayed (1982) showed that the 1000- grain weight was reduced by $12 \%$. Aggarwal et al. (1986) showed that the 1000- grain weight differed among irrigation treatments and it was reduced by water stress. Kobata et al. (1992) showed that the 1000-grain weight was reduced under drought stress. Tawfelis (2006) reported that wheat genotypes differently responded to different environmental conditions. The results indicated that drought and heat stress reduced number of 1000 - grain weight to $9.06 \%$ and $22.06 \%$, respectively, compared to normal condition.

Drought susceptibility index (Table 11) varied greatly from season to season with inconsistent direction. Drought susceptibility index (DSI) were less than unity for seventeen in first and fifteen in each of second and over the two seasons genotypes could be considered tolerant to drought respect to 100 -grain weight.

DSI of the combined means indicated that genotypes Mubarak (0.49), C109 (0.53) and cultivar Giza$168(0.56)$ were the best tolerant genotypes to water stress condition.

These result are in agreement with those obtained by Abo-Sapra (2019) who reported that the Drought susceptibility index varied greatly from year to year. Also, he reported that Giza-168 was the best tolerant genotype for drought condition.

\section{References}

Abd El-Ghany, A.M., H.M. Abouzied and M.S. Badran (2016). Evaluation of Some Egyptian wheat cul- tivars under water stress condition in the north western coast of Egypt. pp. 1-113.

Abd El-Ghany, S.E.A. (2019). Diallel analysis for drought stress related traits in bread wheat (Triticum aestivum L.). M.Sc. Thesis, Dep., Agronomy, Faculty of Agriculture, Sohag University, Egypt.

Abo-Sapra, H.M. (2019). Drought tolerance inheritance of yield and its components in bread wheat. M.Sc. Thesis, Dep., Faculty of Agriculture, Assiut University, Egypt.

Afiah, S.A.; Wafaa A. Hassan; F.Sh. Ahmed and H.J.A. Farag (2018). Response of some promising bread wheat genotypes to drought stress. Egyptian J. of Plant Breed., 22: 1163-1180.

Aggarwal, P.K., G.S. Chaturvedi, A.K. Singh and S.K. Sinha (1986). Performance of wheat and triticale cultivars in a variable soilwater environment. III- source-sink relationships. Field Crops Res., 31: 317- 330 .

Ahmed A.A. (2003). Diallel analysis and stability of yield and yield components in bread wheat (triticum aestivum L. em. Thell).M. Sc. Thesis, Fac. Agric., Assiut Univ., Egypt.

Blum, A. (1988). Plant Breeding for Stress Environments. CRC Press, Boca Raton, FL.

Blum, A. (1996). Yield potential and drought resistance: are they mutually exclusive. Yield potential in wheat: breaking the barriers, 90100.

Braun, H.J.; G. Atlin and T. Payne (2010). Multi-location testing as a tool to identify plant response to global climate change. In Reynolds CRR. (ed.) Climate Change and Crop Production, CABI, London, UK.

Byrne, P.F.; J. Bolanos; G.O. Edmeades and D.L. Eaton (1995). Gains from 
selection under drought versus multilocation testing in related tropical maize populations. Crop Sci., 35: 63-69.

Clarke, J.M.; R.M. De Pauw and T.F./ Townley-Smith (1992). Evaluation of methods for quantification of drought tolerance in wheat. Crop Sci., 32: 423-428.

Denčić, S.; R. Kastori; B. Kobiljski and B. Duggan (2000). Evaluation of grain yield and its components in wheat cultivars and landraces under near optimal and drought conditions. Euphytica, 113(1), 43-52.

El-Rawi, K and A.M. Khalafalla (1980). Design and analysis of agricultural experiments. El -Mousel. Univ. Iraq.

FAOSTAT (2016). Food and Agriculture Organization of the United $\mathrm{Na}$ tions, http://faostat.fao.Org.

Fischer, R.A. and R. Maurer (1978). Drought resistance in spring wheat cultivars. I. Grain yield responses. Australian Journal of Agricultural Research, 29(5), 897-912.

Gomez, K.A. and A.A. Gomez (1984). Statistical Procedures for Agriculture Research. John Wiley and Sons. Inc. New York.

Kadam, S.; Y. Shukla; N. Subhash; C. Singh and K. Suthar (2017). Screening of Wheat Genotypes (Triticum durum L.) in Response to Drought Stress by Some Physiological and Biochemical Indices. Int. J. Pure App. Biosci, 5(3), 969977.

Kheiralla, K.A and A.A. Ismail (1995). Stability analysis for grain yield and some traits related to drought resistance in spring wheat. Assiut J. Agric. Sci., 26: 253-266.

Kheiralla, K.A.; A.A. Ismail and G.R. El-Nagar (1997). Drought tolerance and stability of some spring wheat cultivars. Assiut J. Agric. Sci., 28: 75-88.
Kheiralla, K.A.A; M.A. El-Morshidy, M.H. Motawea and A.A.A. Saeid (2004). Performance and stability of some wheat genotypes under normal and water stress conditions. Assiut J. Agric. Sci., 35: 74-94.

Kirigwi, F.M.; M. Van Ginkel; R. Trethowan; R.G. Sears; R. Sajaram and G.M. Paulsen (2004). Evaluation of selection strategies for wheat adaptation across water regimes. Euphytica, 135: 361-371.

Kobata, T., J.A. Palta and N.C. Turner (1992). Rate of development of post-anthesis water deficits and grain filling of spring wheat. Crop science, 32(5), 1238-1242.

Mohamed, K.A. and A.M. Tammam (1999). Drought resistance of some wheat varieties in Upper Egypt. In Third Conf. on Farm Irrigation and Agroclimatology Programme and Abstracts. January (pp. 25-27).

Pal, M.; K.K. Saxena; J.P. Aggarwal and R.P. Singh (1979). Scheduling of irrigation for wheat under restricted water supply in Bandelkhond region. Indian J. Agron., 24: 58-60.

Rajaram, S. and M. Van Ginkle (2001). Mexico, 50 years of International Wheat breeding Bonjean A.P., Angus W.J. (Eds) the world wheat book: A history of wheat breeding. Lavoisier Publishing, Paris, France, 579-604.

Rajaram, S.; H.J. Braun and M. Van Ginkel (1996). "CIMMYT" approach to breed for drought tolerance. Euphytica, 92: 147-153.

Salem, M.A. (2005). Effect of nitrogen rates and irrigation regimes on yield and yield components of bread wheat (triticum aestivum L.) Genotypes under newly reclaimed land conditions .J. of Agric. Sci., Mansoura Univ., Egypt, 30: 64816490. 
Sayed, H.I. (1982). Response of wheat and triticale cultivars grown under field conditions to drought stress. Wheat information Service, 167: 23-28.

Schmidt, J.W. (1983). Drought resistance and wheat breeding. In Developments in Agricultural and Managed Forest Ecology (Vol. 12, pp. 181-194). Elsevier.

Sio-Se, M.; A.A. Ahmadi; K. Poustini and V. Mohammadi (2006).
Evaluation of drought resistance indices under various environmental conditions. Field Crop Res., 98: 222-229.

Tawfelis, M.B. (2006). Using biplot technique in wheat breeding under different environmental stresses. Egypt J. Plant Breed, 10(2), 167200. 
تقييم تر اكيب وراثية لقمح الخبز تحت ظروف الري العادي و الجاف

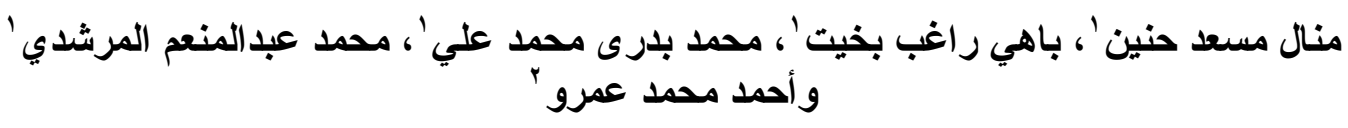

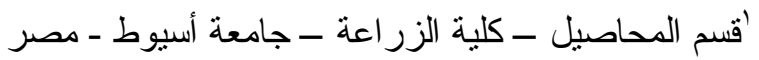

$$
\begin{aligned}
& \text { ' قسم النبات و الميكروبيولوجي ، كلية العلوم - جامعة أسيوط - مصر - لمصر }
\end{aligned}
$$

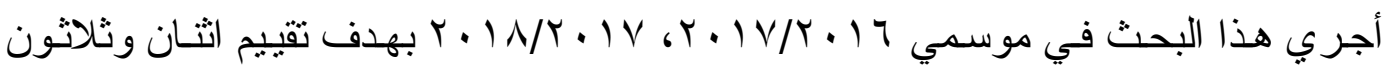

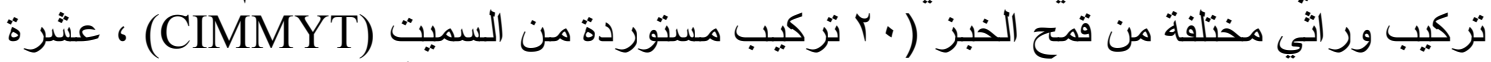

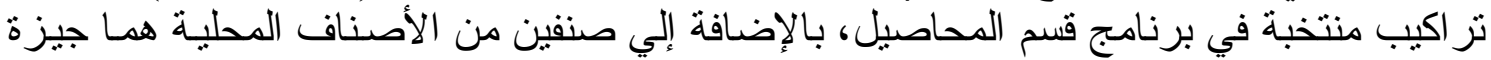

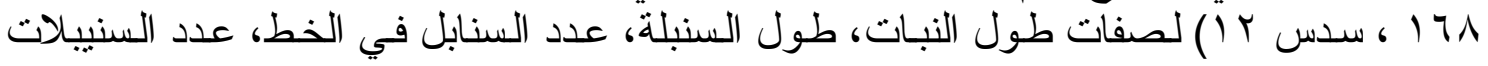

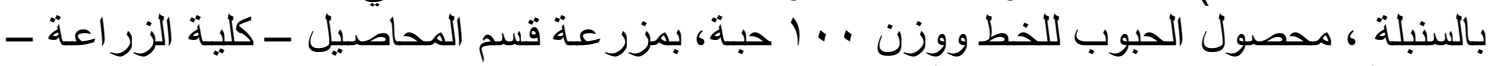

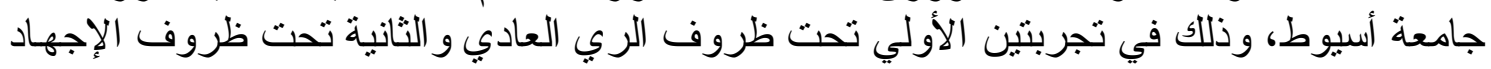

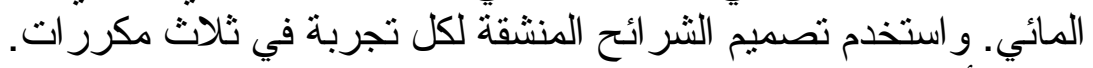

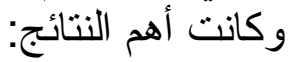

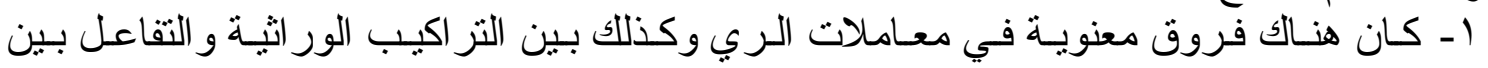

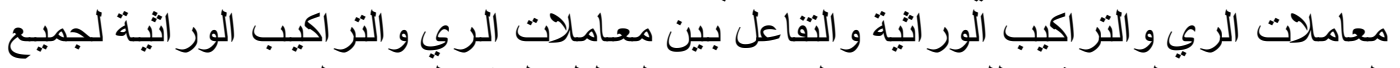

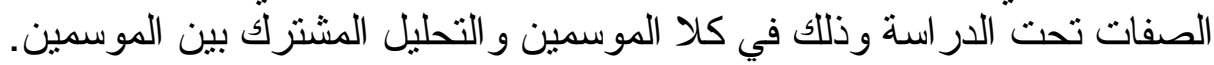

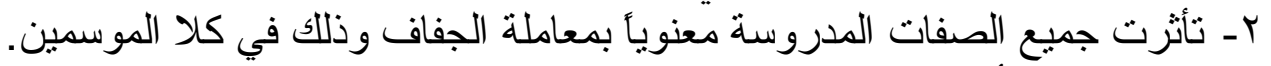

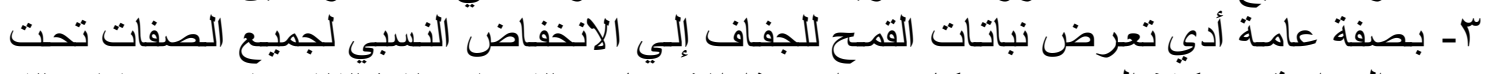

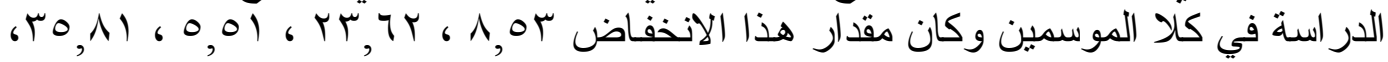

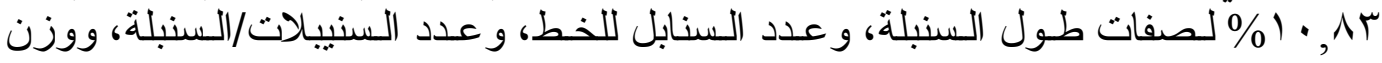

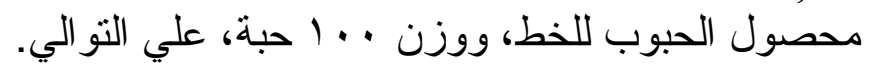

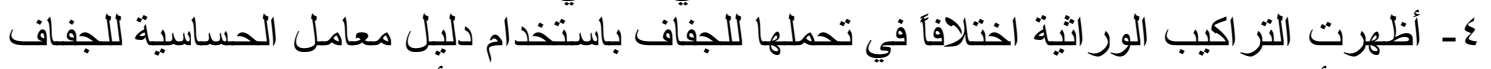

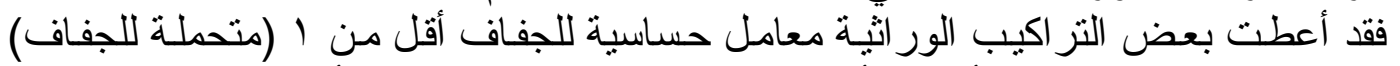

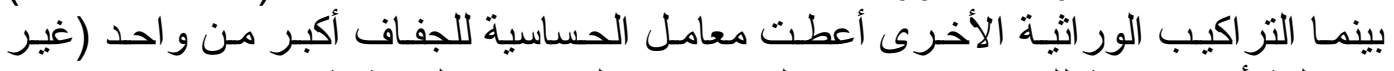

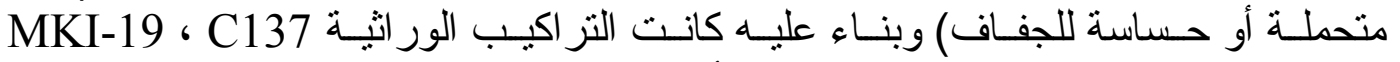
بالإضافة إلي الصنف المنزر ع جيزة 171 أكثر التزر اكيب الور اثئة تحملا للجفاف في كلا

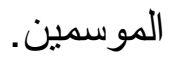

